\title{
Assessment of Quality of Life, Psychological and Functional Status and Disease Activity in Patients with Ankylosing Spondylitis and Fibromyalgia
}

\author{
Mehmet Caglayan ${ }^{1}$, Mehmet Günes ${ }^{2}$, Mehtap Bozkurt ${ }^{1}$, Kemal Nas $^{3}$
}

\begin{abstract}
Objective: Anxiety and depression are psychological disorders which frequently accompany and affect the course of rheumatic diseases. Quality of life is also affected by psychological status. In this study, we aimed to assess psychological status and quality of life in patients with ankylosing spondylitis (AS) and fibromyalgia (FM) and investigate their association with functional status, disease activity and physical limitation.
\end{abstract}

Method: Thirty-seven patients with AS and thirty-four patients with FM were included in this study. The Bath Ankylosing Spondylitis Disease Activity Index (BASDAI) and Bath Ankylosing Spondylitis Functional Index (BASFI) were used for assessment of disease activity and physical functions respectively. The Ankylosing Spondylitis Quality of Life (ASQoL) questionnaire was used for disease-related quality of life in AS patients. Fibromyalgia Impact Questionnaire (FIQ) was used for assessment of functional status in FM patients. Nottingham Health Profile (NHP) and the Hospital Anxiety and Depression Scale (HADS) were, respectively, used for assessment of quality of life and psychological status in groups.

Results: There was no significant difference between the groups in HADS-total, HADS-depression and HADS-anxiety scores ( $p>0.05$ ). However, patients with FM had significantly higher NHP-total and NHP-pain scores compared to patients with AS $(p<0.05)$.

Conclusion: There was no significant difference between the two groups in psychological distress. Higher NHP-pain scores in patients with FM might have been caused by lower pain threshold in these patients. The generalizability of our findings is also limited because of the relatively small sample size. J Clin Exp Invest 2016; 7 (1): 41-46

Key words: Psychological status, functional status, quality of life, ankylosing spondylitis, fibromyalgia

\section{Ankilozan spondilit ve Fibromiyaljili Hastalarda Hastalı Aktivitesi, Hayat Kalitesi ve Psikolojik ve Fonksiyonel Durumun Değerlendirilmesi}

\section{ÖZET}

Amaç: Anksiyete ve depresyon psikolojik hastalıklar olup, romatolojik hastalıklara eşlik etmekte ve seyirlerini etkilemektedir. Hayat kalitesi de psikolojik durumdan etkilenmektedir. Bu çalışmada ankilozan spondilit (AS) ve fibromiyaljili (FM) hastalarda, psikolojik durum ve hayat kalitesini değerlendirmek ve bu durumların fiziksel kısıtııık, fonksiyonel durum ve hastalık aktivitesi ile ilişkisini araştırmayı amaçladık.

Yöntemler: Ankilozan spondilitli 37 ve FM'li 34 hasta çalışmaya alındı. Bath Ankilozan Spondilit Hastalık Aktivite İndeksi (BASDAI) ve Bath Ankilozan Spondilit Fonksiyonel İndeksi (BASFI) sırasıyla hastalık aktivitesi ve fiziksel fonksiyonları değerlendirmek amacıyla kullanıldı. Ankilozan spondilitli hastalarda hastalık ilişkili hayat kalitesini değerlendirmek için Ankilozan Spondilit Hayat Kalitesi (ASQoL) Anketi kullanıldı. Fibromiyaljili hastaların fonksiyonel durumunu değerlendirmek için Fibromiyalji Etki Anketi (FIQ) kullanıldı. Nottingham Sağlık Profili (NHP) ve Hastane Anksiyete ve Depresyon Skalası (HADS) gruplarda sırasıyla hayat kalitesi ve psikolojik durumun değerlendirilmesi için kullanıldı.

Bulgular: HADS Toplam, HADS depresyon ve HADS anksiyete skorları açısından gruplar arasında anlamlı bir farklılık yoktu $(p>0,05)$. Ancak FM'li hastalar, AS'li grupla karşılaştırıldığında anlamlı yüksek NHP-total ve NHP-ağrı skorlarına sahipti $(p<0,05)$.

Sonuç: Psikolojik stres açısından iki grup arasında anlamlı bir farklılık yoktu. Fibromiyaljili hastalardaki yüksek NHP-ağrı skorları bu hastalardaki düşük ağrı eşiği nedeniyle olmuş olabilir. Göreceli küçük örneklem nedeniyle bulgularımızın genellenmesi kısıtlıdır.

Anahtar kelimeler: Psikolojik durum, fonksiyonel durum, hayat kalitesi, ankilozan spondilit, fibromiyalji

${ }^{1}$ Department of Physical Medicine and Rehabilitation, Faculty of Medicine, Dicle University, Diyarbakir, Turkey

${ }^{2}$ Department of Psychiatry, Faculty of Medicine, Dicle University, Diyarbakir, Turkey

${ }^{3}$ Department of Physical Medicine and Rehabilitation, Faculty of Medicine, Sakarya University, Sakarya, Turkey

Correspondence: Mehmet Caglayan,

Dicle University, Faculty of Medicine, Dept. Physical Med.\& Rehabilitation Diyarbakir, Turkey Email: Iftrmehmet63@hotmail.com Received: 18.02.2016, Accepted: 20.03.2016

Copyright (C) JCEI / Journal of Clinical and Experimental Investigations 2016, All rights reserved 


\section{INTRODUCTION}

Fibromyalgia (FM) is a syndrome characterized by widespread and chronic musculoskeletal pain, fatigue, morning stiffness and sleep disturbance. It affects middle-aged women in particular. Its prevalence is thought to be as high as $2 \%$ in general population [1]. It has a negative effect on health-related quality of life (HRQoL) and functional status and often results in disability. It profoundly affects the performance of daily activities both at work and at home $[1,2]$. Previous studies have shown that patients with FM have higher rates of both lifetime and current prevalence of anxiety and depression compared to control subjects [3-5].

Ankylosing spondylitis (AS) is a chronic rheumatic disorder, which affects primarily the axial skeleton and restricts spinal mobility. Apart from axial and articular manifestations, AS may have extra-articular manifestations such as enthesitis and acute anterior uveitis. Involvement of other systems may also occur, such as pulmonary and cardiovascular involvement, neurologic lesions and inflammatory bowel disease [6]. AS may account for inflammation and pain in entheses, joints and spine, which may cause altered physical outcomes such as reduced spinal mobility, stiffness, fatigue, sleep disturbances and bring about psychological disorders such as depression, anxiety and stress [7-9]. Patients with AS suffer chronic pain and stiffness, which may restrict their ability to perform various activities of daily living and impair their mood [10]. Anxiety and depression symptoms are important in determination of outcomes in rheumatic diseases [11].

Chronic rheumatological diseases associated disruptions in physical functions and health status have negative effects on patients' mood and HRQoL. FM has negative impact on mood and HRQoL. Furthermore mental health is more severely affected in FM patients compared to AS patients because of cognitive dysfunctions in some patients. In this study, we aimed to assess psychological distress symptoms and quality of life in patients with ankylosing spondylitis (AS) and fibromyalgia and investigate their association with functional status, disease activity and physical limitation.

\section{METHODS}

Thirty-seven patients (22 males and 15 females) who met the Modified New York Criteria for AS [12] and thirty-four patients (20 females and 14 males) who met the 1990 American College of Rheumatology (ACR) criteria for the classification of FM [13] were included in this study. Data on age, sex, medication and duration of disease were noted. The Bath Ankylosing Spondylitis Disease Activity Index (BASDAI) was used for assessment of disease activity $[14,15]$ the Bath Ankylosing Spondylitis Functional Index (BASFI) was used for assessment of physical functions; [16] and the Ankylosing Spondylitis Quality of Life (ASQoL) questionnaire was used for assessment of disease-related quality of life in patients with AS $[17,18]$. The ASQoL questionnaire consists of 18 yes/no questions. Furthermore, Modified Schober test was administered, and chest expansion was measured. Patients who were administered TNF- $\alpha$ medication over the last 3 months prior to the study were excluded from the study. The Fibromyalgia Impact Questionnaire (FIQ) was used for assessment of severity of disease and functional status in patients with FM $[19,20]$. The FIQ is a self-administered questionnaire which consists of 10 items. The Nottingham Health Profile (NHP) was used for assessment of quality of life in both groups. The NHP consists of 38 questions divided into six subgroups as follows: energy, pain, physical mobility, sleep, emotional reactions and social isolation [21,22]. Lastly, the Hospital Anxiety and Depression Scale (HADS) was used for assessment of depression and anxiety symptoms in both groups. The HADS consists of 14 items divided into two subscales, namely depression and anxiety, each of which is comprised of seven items [23,24]. The exclusion criteria were as follows: presence of systemic diseases such as hypo- or hyperthyroidism, diabetes mellitus and heart failure and history of acute or chronic infections, cerebrovascular diseases, alcohol and/or any substance abuse and major depression. Patients who were currently on anti-depressants and those who received anti-depressant treatment over the last 3 months prior to the study were also excluded from the study.

This study was carried out according to the Helsinki declaration and approved by the Ethics Committee of Dicle University. All the study participants gave their written informed consent to the study after being informed about the study.

\section{Statistical analysis}

Data were expressed as mean \pm SD for continuous variables and as frequency (\%) for categorical variables. The Statistical Package for Social Sciences (SPSS) software was used for all data management and analyses. Student's t-test was used in independent groups, 
and Pearson correlation analysis was used for assessment of correlation between variables. Chi-square test was used for comparison of categorical variables. Multiple regression analysis was used by employing backward selection and stepwise-automated methods for assessment of relationship between relevant variables. A p value less than 0.05 was considered statistically significant.

\section{RESULTS}

There was no significant age difference between the two groups ( $\mathrm{p}>0.05$ ). There was a significant difference between the groups in duration of disease $(p=0.002)$. The mean BASDAI, BASFI, NHP, HADS and FIQ scores are demonstrated in Table 1. All the patients with AS were under the treatment of non-steroidal anti-inflammatory drugs. The mean tender point count was $14 \pm 2$ in patients with FM. Modified Schober and chest expansion values were $4.7 \pm 1.3$ and $4.5 \pm 1.2 \mathrm{~cm}$, respectively in patients with AS. The mean NHP-pain score was $74.01 \pm 26.31$ in patients with FM and $48.63 \pm 21$ in patients with AS. NHP-pain scores were significantly higher in patients with FM $(\mathrm{p}<0.001)$ compared to patients with AS. Significantly higher NHP-total scores were obtained in patients with FM compared to patients with AS $(\mathrm{p}=0.018)$. (Table 1). NHP-pain $(p<0.001)$, NHP-physical functions $(p=0.015)$, NHPenergy $(\mathrm{p}=0.016)$, NHP-social isolation $(\mathrm{p}=0.001)$ and NHP-sleep $(p=0.010)$ scores correlated with ASQoL scores in patients with AS. Correlations between clinical parameters in patients with AS are demonstrated in Table 2. On the other hand, NHP-pain $(\mathrm{p}=0.003)$, NHP-physical activity $(\mathrm{p}=0.011), \quad$ NHP-energy $(\mathrm{p}=0.005)$, NHP-social isolation $(\mathrm{p}=0.045)$ and NHPtotal $(p=0.004)$ scores had a positive correlation with FIQ scores in patients with FM. There was a significant correlation between HADS-depression scores and NHP-sleep scores $(\mathrm{p}=0.001)$ in FN patients. In addition, NHP-sleep scores correlated with HADSanxiety scores $(\mathrm{p}=0.001)$; NHP-pain scores correlated with both HADS-depression $(\mathrm{p}=0.003)$ and HADSanxiety scores $(\mathrm{p}=0.001)$; and NHP-pain $(\mathrm{p}=0,011)$, NHP-physical functions $(\mathrm{p}=0.002), \quad$ NHP-sleep $(p=0.002)$ and NHP-total scores $(p=0.001)$ correlated with HADS total scores in patients with FM. Correlations between clinical parameters in patients with FM are demonstrated in Table 3.
Table 1. Demographic and clinical characteristics of patients with ankylosing spondylitis and fibromyalgia

\begin{tabular}{|c|c|c|c|}
\hline & $\begin{array}{l}\text { Ankylosing spondylitis } \\
\qquad(\mathrm{n}=37)\end{array}$ & $\begin{array}{c}\text { Fibromyalgia } \\
(n=34)\end{array}$ & p \\
\hline Age (mean $\pm S D)$ & $35.3 \pm 12.5$ & $35.7 \pm 11.5$ & NS \\
\hline Duration of disease (mean $\pm S D$ ) (year) & $4 \pm 5.8$ & $3.8 \pm 3.2$ & NS \\
\hline Body mass index $(\mathrm{kg} / \mathrm{m})^{2}$ & $25.5 \pm 5.7$ & $25.3 \pm 3.8$ & NS \\
\hline BASDAI & $3.9 \pm 1.8$ & - & - \\
\hline BASFI & $4 \pm 2.3$ & - & - \\
\hline Chest expansion (cm) & $4.5 \pm 1.2$ & - & - \\
\hline Modified Schober (cm) & $4.7 \pm 1.3$ & - & - \\
\hline ASQoL & $8.1 \pm 4.3$ & - & - \\
\hline HADS-total & $15.08 \pm 6.7$ & $9.2 \pm 3.7$ & 0.249 \\
\hline HADS-depression & $6.9 \pm 3.2$ & $7.1 \pm 3.4$ & 0.829 \\
\hline HADS-anxiety & $8.1 \pm 4$ & $16.3 \pm 6.2$ & 0.423 \\
\hline NHP-pain & $48.6 \pm 21.1$ & $74 \pm 26.3$ & 0.000 \\
\hline NHP-physical function & $41.8 \pm 24.1$ & $44.6 \pm 21.8$ & 0.617 \\
\hline NHP-energy & $47.7 \pm 38.1$ & $64.6 \pm 28.3$ & 0.038 \\
\hline NHP-social isolation & $12.9 \pm 23.6$ & $21.1 \pm 29.9$ & 0.203 \\
\hline NHP-emotional reaction & $46.2 \pm 25.3$ & $48.9 \pm 31$ & 0.682 \\
\hline NHP-sleep & $32.7 \pm 26.6$ & $41.1 \pm 31.2$ & 0.222 \\
\hline NHP-total & $37.5 \pm 19.6$ & $48.7 \pm 19.3$ & 0.018 \\
\hline FIQ & - & $51.7 \pm 17.3$ & - \\
\hline Tender point count & - & $13 \pm 2$ & - \\
\hline
\end{tabular}


Table 2. Correlations between clinical findings in patients with ankylosing spondylitis

\begin{tabular}{|c|c|c|c|c|c|c|c|c|c|c|c|}
\hline & $\begin{array}{l}\text { NHP- } \\
\text { pain } \\
\text { (r) }\end{array}$ & $\begin{array}{c}\text { NHP- } \\
\text { physical } \\
\text { functions } \\
(r)\end{array}$ & $\begin{array}{l}\text { NHP- } \\
\text { energy } \\
(r)\end{array}$ & $\begin{array}{c}\text { NHP- } \\
\text { social } \\
\text { isolation } \\
\text { (r) }\end{array}$ & $\begin{array}{l}\text { NHP- } \\
\text { emotional } \\
\text { reaction } \\
(r)\end{array}$ & $\begin{array}{l}\text { NHP- } \\
\text { sleep } \\
(r)\end{array}$ & $\begin{array}{l}\text { NHP- } \\
\text { total } \\
(r)\end{array}$ & $\begin{array}{c}\text { HADS- } \\
\text { depression }\end{array}$ & $\begin{array}{l}\text { HADS- } \\
\text { anxiety }\end{array}$ & $\begin{array}{l}\text { HAD- } \\
\text { total }\end{array}$ & ASQoL \\
\hline ASQoL & $0.590^{*}$ & $0.396^{*}$ & $0.393^{*}$ & $0.538^{*}$ & 0.310 & $0.419^{*}$ & 0.042 & $0.500^{*}$ & $0.328^{*}$ & $0.437^{*}$ & 1 \\
\hline BASDAI & 0.121 & 0.258 & 0.195 & 0.205 & 0.313 & 0.037 & $0.224^{*}$ & 0.223 & 0.290 & $0.28^{*}$ & $0.477^{*}$ \\
\hline BASFI & $0.429^{*}$ & $0.477^{*}$ & 0.159 & 0.238 & 0.006 & 0.231 & $0.14^{*}$ & 0.292 & 0.232 & 0.279 & $0.502^{*}$ \\
\hline HADS-depression & $0.630^{*}$ & 0.170 & $0.631^{*}$ & $0.412^{*}$ & $0.441^{*}$ & $0.693^{*}$ & 0.262 & 1 & $0.718^{*}$ & $0.910^{*}$ & $0.500^{*}$ \\
\hline HADS-anxiety & $0.526^{*}$ & 0.141 & $0.581^{*}$ & 0.297 & 0.282 & 0.555 & 0.145 & $0.718^{*}$ & 1 & $0.942^{*}$ & $0.328^{*}$ \\
\hline HADS-total & $0.618^{*}$ & 0.166 & $0.650^{*}$ & $0.376^{*}$ & $0.381^{*}$ & $0.665^{*}$ & 0.213 & $0.910^{*}$ & $0.942^{*}$ & 1 & $0.437^{*}$ \\
\hline
\end{tabular}

BASDAI Bath AS Disease Activity Index, BASFI Bath AS Functional Index, ASQoL AS Quality of Life, HADS Hospital Anxiety and Depression Scale, NHP Nottingham Health Profile, $* p<0.05$

Table 3. Correlations between clinical findings in patients with fibromyalgia

\begin{tabular}{lcccccccccc}
\hline & $\begin{array}{c}\text { NHP- } \\
\text { pain } \\
(\mathbf{r})\end{array}$ & $\begin{array}{c}\text { NHP- } \\
\text { physical } \\
\text { functions } \\
(\mathbf{r})\end{array}$ & $\begin{array}{c}\text { NHP- } \\
\text { energy } \\
(\mathbf{r})\end{array}$ & $\begin{array}{c}\text { NHP- } \\
\text { social } \\
\text { isolation } \\
(\mathbf{r})\end{array}$ & $\begin{array}{c}\text { NHP- } \\
\text { emotional } \\
\text { reaction } \\
(\mathbf{r})\end{array}$ & $\begin{array}{c}\text { NHP- } \\
\text { sleep } \\
(\mathbf{r})\end{array}$ & $\begin{array}{c}\text { NHP- } \\
\text { total } \\
(\mathbf{r})\end{array}$ & $\begin{array}{c}\text { HADS- } \\
\text { depression }\end{array}$ & $\begin{array}{c}\text { HADS- } \\
\text { anxiety }\end{array}$ & $\begin{array}{c}\text { HAD- } \\
\text { total }\end{array}$ \\
\hline FIQ & $0.488^{*}$ & $0.429^{*}$ & $0.475^{*}$ & $0.346^{*}$ & 0.090 & 0.302 & $0.477^{*}$ & 0.230 & 0.183 & 0.095 \\
HADS-depression & $0.497^{*}$ & $0.522^{*}$ & 0.254 & 0.314 & 0.080 & $0.644^{*}$ & $0.631^{*}$ & 1 & $0.858^{* *}$ & $0.517^{*}$ \\
HADS-anxiety & $0.531^{*}$ & $0.592^{*}$ & 0.250 & 0.305 & 0.156 & $0.657^{*}$ & $0.660^{*}$ & $0.858^{*}$ & 1 & $0.883^{*}$ \\
HADS-total & $0.431^{*}$ & $0.510^{*}$ & 0.185 & 0.221 & $0.186^{*}$ & $0.507^{*}$ & $0.523^{*}$ & $0.517^{*}$ & $0.883^{*}$ & 1 \\
\hline
\end{tabular}

HADS Hospital Anxiety and Depression Scale, NHP Nottingham Health Profile, FIQ Fibromyalgia impact questionnaire, ${ }^{*} p<0.05$,

In this study, multiple regression analysis was used by employing backward selection method in patients with AS and FM. In the analysis, QoL was considered dependent variable whereas BASDAI, BASFI, HADS-total, HADS-depression and HADS-anxiety were considered independent variables in patients with AS. Results of the analysis showed that BASDAI $(\beta=0.284, t=2.0, p=0.05)$ and HADS-depression $(\beta=0.354, \mathrm{t}=2.6, \mathrm{p}=0.013)$ were the independent variables which had an impact on ASQoL. On the other hand, FIQ was considered dependent variable whereas NHP-pain, NHP-physical function, NHP-energy, NHP-social isolation and NHP total were considered independent variables in patients with FM, and it was found that NHP-pain was the only independent variable which had an impact on FIQ scores $(\beta=0.35, \mathrm{t}=$ $2.1, \mathrm{p}=0.04)$.

\section{DISCUSSION}

In rheumatic diseases, patients may experience impaired functional, psychological and social status. Anxiety and depression are psychological disorders which frequently accompany and affect the course of rheumatic diseases [25]. Quality of life is also affected by psychological status [26]. Psychological problems may cause decreased strength to cope with a rheumatic disease and affect the medical treatment and rehabilitation program in patients with AS and FM. Furthermore, pain, physical limitation and stiffness suffered by the patients may affect their quality of life [27]. Ovayolu et al. suggested that AS and FM had a negative effect on the health-related quality of life in patients with AS and FM [10].

Patients with FM may experience difficulties in carrying out their work as well as activities of daily living because of chronic pain and physical and emotional disability $[28,29]$. In this study, we found higher NHP-pain scores in patients with FM compared to patients with AS, which might have been caused by lower pain threshold in patients with FM [30].

To the best of our knowledge, this is the first study in the literature comparing psychological status of patients with AS to that of patients with FM. However, there are a few studies in the literature comparing functional status of patients with AS and FM to that of healthy controls [10]. In the present study, we compared HADS-depression, HADS-anxiety and HADS- 
total scores of patients with AS to those of patients with FM. However, we could not find any significant difference between the two groups in these parameters. On the other hand, HADS-anxiety and HADS-depression scores had a positive correlation with ASQoL scores in patients with AS. Psychological status of patients with AS may affect their quality of life. Baysal et al. suggested that higher HADS-depression and HADSanxiety scores meant a poorer functional outcome and reduced quality of life. Furthermore, they concluded that psychological status of the patients had a close relation with quality of life [26]. In the present study, multivariate regression analysis showed that BASDAI and HADS-depression scores were the independent variables which had an impact on ASQoL. The clinical symptoms of AS such as pain, physical limitation and stiffness may cause restrictions in daily living, and all these factors may lead to depression, which may result in reduced quality of life.

The FIQ helps assess functional status and severity of disease including ability of the patient to work, as well as pain, fatigue, tiredness, stiffness, anxiety and depression in patients with FM $[19,20]$. In the present study, HADS-scores did not correlate with FIQ scores in patients with FM. This result might have been influenced by the other variables of the FIQ. NHP-emotional reaction ad NHP-sleep sub-scores did not correlate with FIQ scores, either. However, the rest of the NHP scores correlated with FIQ scores. This result indicates a close correlation between quality of life and functional status in patients with FM. In multivariate regression analysis, NHP-pain was the sole independent factor which had an impact on the FIQ scores.

In this study, NHP-total scores were significantly higher in patients with FM compared to patients with AS; however, no significant difference was found between the groups in HADS scores. Hyphantis et al. compared psychological distress symptoms and illness perceptions in patients with AS and rheumatoid arthritis (RA). They showed that there was no significant difference between the two groups with regard to psychological distress and HRQoL.

In the present study, higher NHP-total scores in patients with FM might have been caused by the widespread pain experienced by the patients with FM which demonstrates similarities to neuropathic pain in clinical findings, pathophysiology and neuropharmacology $[30,31]$. On the other hand patients with FM patients have symptoms such as fatigue and subjective weakness in addition to pain [1]. This symptoms reflected the high both NHP-energy and NHP-pain scores which also influenced the NHP total scores. In conclusion patients with FM experience higher pain scores compared to patients with AS, which might have been caused by lower pain threshold in patients with FM.

There is no significant difference between patients with FM and AS in psychological distress; however, psychological status is associated with disease-related quality of life in patients with AS. Patients with FM experience poorer quality of life compared to patients with AS.

Our study shows that FM and AS associated changes in daily activities have negative impacts on patients' functions. Health care providers might make the patients to improve their levels of awareness about their disease and provide patients with the necessary support materials to help them cope with their diseases.

This study has some limitations. One of these limitations is neither patients with AS nor FM was questioned about the presence of psychological diseases such as bipolar affective disorders or schizophrenia. Other important limitation is its cross-sectional design. The generalizability of our findings is also limited because of the relatively small sample size. There is a need for further research with lager samples to replicate the findings of this study.

Declaration of Conflicting Interests: The authors declare that they have no conflict of interest.

Financial Disclosure: No financial support was received.

\section{REFERENCES}

1. Wolfe F, Ross K, Anderson J, et al. The prevalence and characteristics of fibromyalgia in the general population. Arthritis Rheum 1995;38:19-28.

2. Yoshikawa GT, Heymann RE, Helfenstein MJ. A comparison of quality of life, demographic and clinical characteristics of Brazilianmen with fibromyalgia syndrome with male patients with depression. Rheumatol Int 2010;30:474-478,

3. Epstein SA, Kay G, Clauw D, et al. Psychiatric disorders in patients with fibromyalgia. A multicenter investigation. Psychosomatics 1999;40:57-63.

4. Ahles TA, Khan SA, Yunus MB, et al. Psychiatric status of patients with primary fibromyalgia, patients with rheumatoid arthritis, and subjects without pain: a blind comparison of DSM-III diagnoses. Am J Psychiatry 1991;148:17211726 
5. Krag NJ, Norregaard J, Larsen JK, Danneskiold-Samsoe B. A blinded, controlled evaluation of anxiety and depressive symptoms in patients with fibromyalgia, as measured by standardized psychometric interview scales. Acta Psychiatr Scand 1994;89:370-375.

6. Klippel JH, Stone JH, Crofford LJ, White PH (eds). Primer on the rheumatic diseases, $13^{\text {th }}$ edn. Springer, New York, 2008.

7. Martindale J, Smith J, Sutton CJ, et al. Disease and psychological status in ankylosing spondylitis. Rheumatology 2006;45:1288-1293.

8. Lim HJ, Moon YI, Lee MS. Effects of home-based Daily exercise therapy on joint mobility, daily activity, pain, and depression in patients with ankylosing spondylitis. Rheumatol Int 2005;25:225-229.

9. Calin A, Edmunds L, Kennedy LG. Fatigue in ankylosing spondylitis-why is it ignored? J Rheumatol 1993;20:991995.

10. Ovayolu N, Ovayolu, Karadag G. Health-related quality of life in ankylosing spondylitis, fibromyalgia syndrome, and rheumatoid arthritis: a comparison with a selected sample of healthy individuals Clin Rheumatol 2011;30:655-664.

11. Hyphantis T, Kotsis K, Tsifetaki N, et al. The relationship between depressive symptoms, illness perceptions and quality of life in ankylosing spondylitis in comparison to rheumatoid arthritis. Clin Rheumatol. 2013;32:635-644.

12. Van der Linden S, Valkenburg HA, Cats A. Evaluation of diagnostic criteria for ankylosing spondylitis. A proposal for modification of the New York criteria. Arthritis Rheum 1984;27:361-368

13. Wolfe F, Smythe HA, Yunus MB et al. The American College of Rheumatology 1990 criteria for the classification of fibromyalgia. Arthritis Rheum 1990;33:160-172.

14. Garrett S, Jenkinson T, Kennedy LG, et al. A new approach to defining disease status in ankylosing spondylitis: the bath ankylosing spondylitis disease activity index. J Rheumatol 1994;21:2286-2291.

15. Akkoc Y, Karatepe AG, Akar S, et al. A Turkish version of the Bath Ankylosing Spondylitis Disease Activity Index: reliability and validity. Rheumatol Int 2005;25:280-284.

16. Calin A, Garrett S, Whitelock H, et al. A new approach to defining functional ability in ankylosing spondylitis: the development of the Bath Ankylosing Spondylitis Functional Index .J Rheumatol 1994;21:2281-2285.

17. Doward LC, Spoorenberg A, Cook SA. Development of ASQoL: a quality of life instrument specific to ankylosing spondylitis. Ann Rheum Dis 2003;62:20-26.
18. Duruöz MT, Doward L, Turan Y, et al. Translation and validation of the Turkish version of the ankylosing spondylitis quality of life (ASQoL) Questionnaire. Rheumatol Int. 2013;33:2717-2722.

19. Burckhardt CS, Clark SR, Bennett RM. The fibromyalgia impact questionnaire: development and validation. J Rheumatol 1991;18:728-733.

20. Sarmer S, Ergin S, Yavuzer G. The validity and reliability of the Turkish version of the fibromyalgia impact questionnaire. Rheumatol Int 2000;20:9-12.

21. Hunt SM, McKenna SP, McEwen J, et al. The Nottingham Health Profile: subjective health status and medical consultations. Soc Sci Med A 1981;15:221-229.

22. Kucukdeveci AA, McKenna SP, Kutlay S, et al. The development and psychometric assessment of the Turkish version of the Nottingham health profile. Int J Rehabil Res 2000;23:31-38.

23. Zigmond AS, Snaith PR. The hospital anxiety and depression scale. Acta Psychiatr Scand 1983;67:361-370.

24. Aydemir O, Guvenir T, Kuey L, Kultur S. Validity and reliability of Turkish version of hospital anxiety and depression scale. Turk Psikiyatri Dergisi 1997;8:280-287.

25. Wells KB, Golding JM, Burnam MA. Psychiatric disorder in a sample of the general population with and without chronic medical conditions. Am J Psychiatry 1988;145:976-981.

26. Baysal O, Durmus B, Ersoy Y, et al. Relationship between psychological status and disease activity and quality of life in ankylosing spondylitis. Rheumatol Int 2011;31:795-800.

27. Ozgul A, Peker F, Taskaynatan MA, et al. Effect of ankylosing spondylitis on health-related quality of life and different aspects of social life in young patients. Clin Rheumatol 2006;25:168-174

28. Zautra AC, Fasman R, Parish BP, Davis MC. Daily fatigue in women with osteoarthritis, rheumatoid arthritis, and fibromyalgia. Pain 2007;128:128-135.

29. Ofluoglu D, Berker N, Guven Z, et al. Quality of life in patients with fibromyalgia syndrome and rheumatoid arthritis. Clin Rheumatol 2005;24:490-492.

30. Staud R, Spaeth M. Psychophysical and neurochemical abnormalities of pain processing in fibromyalgia CNS Spectr 2008;13:12-17.

31. Sumpton JE, Moulin DE. Fibromyalgia. Handb Clin Neurol 2014;119:513-527. 